Original Article

\title{
ANTIBIOTIC PRESCRIPTION TO PEDIATRIC IN HOSPITAL BENGKULU, INDONESIA: ATC/DDD INDEX
}

\author{
ZAMHARIRA MUSLIM \\ Department of Pharmacy, Health Polytechnic, Ministry of Health Bengkulu, Bengkulu 38225, Indonesia \\ Email: zamhariramuslim@yahoo.com
}

Received: 14 Feb 2018 Revised and Accepted: 22 Mar 2018

\begin{abstract}
Objective: The aim of this study was to evaluate the utilization of antibiotics for children in the General Hospital of Dr. M. Yunus Bengkulu, Indonesia by using the ATC/DDD index, which is accepted as a standard method.

Methods: This study was descriptive analytic research with qualitative methods. Observations conducted over six months collecting retrospective prescribing data antibiotics in children admitted in January to June 2014. Data obtained assessed antibiotics prescribed in a quantity which is calculated using ATC/DDD index. In this study, DDDs of anti-infective agents are listed for systemic use, according to ATC/DDD 2016 Index. Data pediatric patients hospitalized amounted to 447 patients while fulfilling the inclusion criteria amounted to 103 medical records and the use of antibiotics which recorded 175 prescriptions.
\end{abstract}

Results: The kind of antibiotics that are widely used are gentamicin (34.9\%) and ampicillin (34.3\%). The highest ACI based group is penicillin group antibiotics (ampicillin) is 26 DDD/100 bed-days. Highest DDDs in this study is ampicillin (101.7). Utilization of antibiotics in hospitals in Bengkulu, Indonesia to pediatric patient higher than suggested by the WHO is based on a quantitative analysis using the ACT/DDD index.

Conclusion: Analysis of antibiotic use in children is not rationally quantitatively seen from the total value of ACI in one of the government hospital is very high compared to WHO standard and based on the most antibiotic type was ampicillin followed by gentamicin.

Keywords: Antibiotic, Pediatric, Prescription, ATC/DDD index

(C) 2018 The Authors. Published by Innovare Academic Sciences Pvt Ltd. This is an open access article under the CC BY license (http://creativecommons.org/licenses/by/4.0/] DOI: http://dx.doi.org/10.22159/ijpps.2018v10i5.25291

\section{INTRODUCTION}

Prescribing antibiotics in pediatric patients are a major concern in terms of public health because the infection is a major cause of illness in children and the number of prescribing antibiotics in preschool children is one of the three recipes [1]. At the hospital northern European countries, the use of antibiotics has a range of 16.6-25\% [2], in ICU at Sultan Qaboos University Hospital, a teaching hospital in Oman, antibiotics accounted for $12 \%$ of the total drugs prescribed [3]. A Study in the surgical clinic of Dr. H. Marzoeki Mahdi Hospital, Bogor, Indonesia showed all patients received prophylactic antibiotics before surgery and Cefotaxime (87.8\%) was the most commonly used antibiotics for surgical prophylaxis [4]. Inappropriate antibiotic usage often leads to many problems such as; the resistance of antibiotics, negative effects on the ecological balance, side effects on patients, triggering of super infections and increase in treatment costs [5].

The antibiotic has a different unit dose of daily administration, it needs a specific standardized method to evaluate in-hospital antibiotic use [6]. WHO has suggested a standard method for evaluating drug usage quantitatively by using the ATC/DDD index. ATC/DDD index is a universal parameter used in the evaluation of antibiotic use [7]. The aim of the ATC/DDD methodology is to serve as a tool for drug utilization study in order to improve a quality of drug use. One component of this is the presentation and comparison of drug consumption statistics at international and other levels. The classification of a substance in the ATC/DDD index is not a recommendation for use, nor does it imply any judgments about the efficacy or relative efficacy of drugs and groups of drugs [8]. DDD 100 bed-days has been used internationally in the comparison of inhospital and outpatient antibiotic use, and such data have been used to compare and to throw light on the national level of antibiotic use and resistance relationship [9]

Up to now didn't much research in Indonesia on the evaluation of the use of antibiotics in children hospitalized government by using
ATC/DDD index. This study is the first in the province, of Bengkulu related to the evaluation of the use antibiotic. Therefore, a follow-up study in the government hospital sector was needed to investigate the current prescribing practices and subsequently Evaluate the performance of healthcare providers in the Rational Use of Medicines (RUM) [10].

Indonesia has about 2488 hospitals comprising government hospitals and private hospitals. In Bengkulu province, there are 16 government hospitals and 4 private hospitals. The largest hospital in the province of Bengkulu is the General Hospital of Dr. M. Yunus Bengkulu who has 6 wards and divided into 3 classes of services. This study evaluated the use of antibiotics in child wards that each month had an average patient number of 109 patients. The treated patients were divided into mostly using the national health insurance BPJS.

\section{MATERIALS AND METHODS}

\section{Objectives}

The aim of this study was to evaluate the utilization of antibiotics in the General Hospital of Dr. M. Yunus Bengkulu, Indonesia by use ATC/DDD index, which is accepted as a standard method.

\section{Methods}

\section{Ethical considerations}

The study was approved by Ethics Commission Politeknik Kesehatan Kementerian Kesehatan Bengkulu, Indonesia Number. DM.01.04/ $023 / 3 /$ XII/2016.

\section{Study design}

This research is descriptive analytic research with quantitative methods. Data collection

Observations conducted over six months collecting retrospective prescribing data antibiotics in children admitted to one of the 
General Hospital of Dr. M. Yunus Bengkulu, Indonesia in January to June 2014. Data were collected from patient charts using a standard form; patient personal information, underlying disease, the name of the antibiotic in use, dosage, usage, duration and reason of antibiotic use (prophylaxis, empirical, microbiologically proven infection) were recorded on the data sheet.

\section{Sample size}

Pediatric patients hospitalized from January to June 2014 amounted to 447 patients while fulfilling the inclusion criteria amounted to 103 medical records and the use of antibiotics which recorded 175 prescriptions.

\section{Inclusion criteria}

Prescription antibiotics (oral and injectable) written for the diagnosis of infection in children in the form of bearing the generic name and branded generics.

\section{Exclusion criteria}

Prescription of antibiotics in the form of semi-solid (creams and ointments) and drops were excluded.

\section{Data analysis}

Data obtained were assessed the use of antibiotics in a quantity which is calculated using ATC/DDD index. In this study, DDDs of anti-infective agents are listed for systemic use, according to ATC/DDD 2016 Index.
The DDD is the assumed average maintenance dose per day for a drug used for its main indication in adults and a DDD will only be assigned to drugs that already have an ATC code. The DDD value in grams of every drug is defined by the WHO and is periodically updated. DDD values of every antibiotic are calculated separately [8]. In this calculation method, the form used for in-bed patients is the ratio of the total DDD per 100bed-days. This index is called antimicrobial consumption index (ACI) [6]. Calculate ACI use equation [11]:

$$
A C I=D D D / \text { patient bed }- \text { days } \times 100
$$

\section{RESULTS}

Pediatric patients receiving care in the hospital to get the various combinations of antibiotics used. From the characteristic patients showed most patients are males compared to females. Grouping the data by age shows that the age of 1 to $3 \mathrm{y}$ has a rate of infection that is quite high at $28.2 \%$ and the lowest in the age group over $12 \mathrm{y}$ $(6.8 \%)$ with an average age of $4.2 \mathrm{y}$ (table 1$)$.

This study describes the use of antibiotics as much as 175 times that consists of 7 types and divided into 5 groups of antibiotics. Antibiotic use in pediatric patients is the use of gentamicin (34.9\%) and ampicillin (34.3\%). Single antibiotic prescription or in combination found in this study observation. Single antibiotic use as much as $40.8 \%$, the combination of two types of antibiotics $48.5 \%$ and the use of three types of combinations of antibiotics $10.7 \%$. The most antibiotic combination is ampicillin-gentamicin is $41.75 \%$.

Table 1: Characteristic population

\begin{tabular}{ll}
\hline Variable & $\mathbf{n ~ ( \% )}$ \\
\hline Sex & $66(64.1)$ \\
Male & $37(35.9)$ \\
Female & \\
Age & \\
Age $<1$ y & $22(21.4)$ \\
$1 \leq$ Age $<3$ y & $29(28.2)$ \\
$3 \leq$ Age $<6$ y & $21(20.4)$ \\
$6 \leq$ Age $<12$ y & $24(23.3)$ \\
12 y $\leq$ Age & $7(6.8)$ \\
\hline
\end{tabular}

*Mean of age is $4.2 \mathrm{y}$ old.

Rate rationality use of antibiotics quantitatively calculated using the method of ACI by comparing the value of ACI standards set by WHO. ACI value is considered high when exceeding the standard DDD value set by the WHO. The total number of ACI values in this study was 50.9 DDD/100 bed-days. The highest ACI based group is penicillin group antibiotics (Ampicillin) is 26 DDD/100 bed-days. Highest Defined Daily Dose (DDDs) in this study based kind of antibiotic is ampicillin (101.7) (table 2).

Table 2: Antibiotics usage based on ATC/DDD index

\begin{tabular}{|c|c|c|c|c|c|c|}
\hline Antibiotics group & Antibiotics & ATC Code & n (\%) & DDD (WHO) & DDDs & ACI \\
\hline Penicillin & Ampicillin & J01CA01 & $60(34.3 \%)^{*}$ & 2 & $101.7^{* * *}$ & $26.0^{* *}$ \\
\hline \multirow[t]{3}{*}{ Third generation cephalosporins } & Cefotaxime & J01DD01 & $34(19.4 \%)$ & 4 & 20.1 & 5.1 \\
\hline & Ceftriaxone & J01DD04 & $12(6.9 \%)$ & 2 & 17.6 & 4.5 \\
\hline & Ceftazidime & J01DD02 & $1(0.6 \%)$ & 4 & 0.3 & 0.1 \\
\hline Amphenicol & Chloramphenicol & J01BA01 & $6(3.4 \%)$ & 3 & 10.4 & 2.7 \\
\hline Aminoglycosides & Gentamicin & J01GB03 & $61(34.9 \%)^{*}$ & 0.24 & 47.8 & 12.2 \\
\hline Carbapenems & Merophenem & J01DH02 & $1(0.6 \%)$ & 2 & 1.3 & 0.3 \\
\hline Total & & & & & 199.2 & 50.9 \\
\hline
\end{tabular}

*Highest antibiotic usage, ${ }^{* *}$ Highest antimicrobial consumption index (ACI), ${ }^{* * *}$ Highest Defined Daily Dose (DDDs)

\section{DISCUSSION}

This study shows as your child grows older, it will decrease the possibility of infection. The results of previous studies which stated that the increasing age of the diminishing also the possibility of infection [12]. Children will get the infection 3 to 6 times per year, but some people get it more often, especially during the year to 2 to 3 of their lives [13]. The incidence of infection in children is very high, it is because the immune system of children at this age doesn't work well in preventing infection [12]. Antibiotics that are often prescribed in children are ampicillin and gentamicin and are often given in combination. Compared with studies conducted in India on antibiotic use in children, antibiotics cephalosporins (cefixime and cefotaxime) are often prescribed in children [14].

The use of gentamicin and ampicillin widely used as an empirical therapy of infection in children. Gentamicin should be used with caution in infants and toddlers. Combination antibiotic gentamicin 
and ampicillin are used as the first-line antibiotic for pediatric patients. This is due to gentamicin in combination with ampicillin produce a strong bactericidal effect, partly due to the increase in drug absorption resulting from inhibition of cell wall synthesis. Penicillin changes the structure of the cell wall so as to facilitate the penetration of gentamicin into bacteria [15]. The purpose of using a combination of antibiotics is increasing the activity of the antibiotics in specific infections (synergistic or additive effect), addressing mixed infections that can't be tackled by one type of antibiotics and resolve cases of life-threatening infections of unknown bacteria causing the infection [16]. According to the ARPAC (Antibiotic Resistance, Prevention, and Control) project, all hospitals often use penicillin group, followed by non-penicillin beta-lactam and fluoroquinolones [17]. In this study antibiotic administration is not based on bacteriological examination because it does not have a microbiology laboratory that is standard for the examination of bacteria if the patient is infected with the infection. Antibiotics are used as a general therapy based on clinical conditions observed in pediatric patients.

Doses for individual patients and patient groups will often differ from the DDD and will necessarily have to be based on individual characteristics (e. g. age and weight) and pharmacokinetic considerations. DDD is the average recommended maintenance dose per day for a drug used for the main indication in adults. Analysis of the use of antibiotics in children is not possible using existing rough sales data in the DDD but using the specified daily dose and indication in a population of children can be used and compared with values DDD of WHO [8]. To analyze the average drug use inpatient hospital use DDD/100 d of hospitalization, while in outpatient or community, especially the therapy of chronic disease using DDD/1,000 d of hospitalization $[8,16]$.

The total value of ACI in this study is very high that is $50.9 \mathrm{DDD} / 100$ bed-days compared to WHO standard 17.24 DDD/100 bed-days. According to Akalın et al.'s study [18] in a university hospital, the $\mathrm{ACI}$ in 2009 was found to be $64.5 \mathrm{DDD} / 100$ bed-days while in 2010 70.5 DDD/100 bed-days, Sözen et. al's study [6] in Isparta State Hospital, Turkey, the ACI was found 55.1 DDD/100 bed-days in 2011. In a study by Vaccheri et al. [19] conducted in a university hospital in Italy, it was shown that a number of antibiotics used, risen from $64.9 \mathrm{DDD} / 100$ bed-day in 2002 to $76.7 \mathrm{DDD} / 100$ beddays in 2004. These ACI values are higher than our study. A similar study conducted at Hospital Infantile de Mexico in 2005 and 2006 with a value of ACI in 2005 amounted to 89.91 DDD/100 bed-days and amounted to 93.88 DDD/100 bed-days in 2006. Antibiotics are the biggest ACI values are class $\beta$-lactam with $\mathrm{ACI}$ value amounting to $36 \mathrm{DDD} / 100$ bed-days in 2005 and $30.44 \mathrm{DDD} / 100$ bed-days in 2006 [20]. Based on calculations performed ACI values obtained the largest and exceed the standards set by the WHO, namely the use of ampicillin with 26 DDD/100 bed-days followed by gentamicin amounted to $12.2 \mathrm{DDD} / 100$ bed-days.

In another study on the use of antibiotic therapy combination of ampicillin and gentamicin in hospitals Dr. M. Yunus Bengkulu of 303 pediatric patients, 103 patients received ampicillin and gentamicin combination therapy, which is the first-line antibiotic therapy at the Hospital [21]. The results of a study on the use of antibiotics are not only compared to countries but also compared between hospitals in the same country. The differences obtained will describe the relationship the hospital and the patient's condition, the policy of the use of antibiotics in hospitals, physician preference and the differences in the education and health systems [22].

Some factors that may increase the value of DDD/100 bed-days are disposable dose, the rules of use and length of stay (LOS). ACI value is inversely proportional to LOS and therefore the greater the value of LOS, ACI gets smaller. The high ACI value in this study indicates that there was excessive dosing of antibiotics in children and describes the dosing is not in accordance with the recommendations of WHO. In this study, the value of ACI to be high due to the use of empirical antibiotic therapy, while the diagnosis of infection has not been done well so happens increased amount of use of antibiotics, especially ampicillin and gentamicin. This study offers information on the pattern and trend of antibiotic use in a sample of Indonesia hospitals, only based on hospital pharmacy records. Our study carried out with a point-prevalence method has certain limitations such as being single-centred, short-time data collection and only antimicrobial use in paediatrics.

The antibiotics prescribed in pediatric patients need more attention by health professionals. Selection of the type and amount of antibiotics in children in several hospitals today is less precise, look at the amount of penicillin usage are very high. The increasing number of incidents of resistance is strongly influenced by the pattern of antibiotics prescribing in the treatment of infections. Before giving antibiotic therapy to patients, the bacteriological examination should be done to determine the bacteria that cause infection and bacterial resistance test so that the type of antibiotics used rationally.

\section{CONCLUSION}

Analysis of antibiotic use in children is not rationally quantitatively seen from the total value of ACI in one of the government hospitals is very high compared to WHO standard and based on the most antibiotic type was ampicillin followed by gentamicin.

\section{ACKNOWLEDGEMENT}

I would like to express my sincere thanks to Badan Pengembangan dan Pemberdayaan Sumber Daya Manusia Kesehatan, Director of Politeknik Kesehatan Kementerian Kesehatan Bengkulu and Dr. M. Yunus General Local Hospital Bengkulu, Indonesia for their excellent technical assistance and for giving the permission to conduct this research in their facilities.

\section{LIMITATION}

This study was conducted in a short duration due to the research schedule set by the funder. Hospitals evaluated for the prescription of antibiotics have not used a computerized drug registration system so there may be missing data.

\section{ABBREVIATION}

WHO: World Health Organization, ATC/DDD: Anatomical Therapeutic Chemical/Defined Daily Doses; ACI: Antimicrobial Consumption Index; BPJS: Badan Penyelenggara Jaminan Sosial.

\section{AUTHOR CONTRIBUTION}

All authors contributed equally. All authors read and approved the final manuscript.

\section{CONFLICT OF INTERESTS}

None

\section{REFERENCES}

1. Thrane N, Olesen C, Schønheyder HC, Sørensen HT. Socioeconomic factors and prescription of antibiotics in 0-to 2year-old danish children. J Antimicrob Chemother 2003;51:683-9.

2. Vlahovic-Palcevski V, Morovic M, Palcevski G. Antibiotic utilization at the university hospital after introducing an antibiotic policy. Eur J Clin Pharmacol Springer 2000;56:97101.

3. Al-Zakwani IS, Al-thuhli M, Al-hashim A, Balushi K Al. Drug utilization pattern in an intensive care unit at a tertiary care teaching hospital in Oman. Asian J Pharm Clin Res 2017;10:194-7.

4. Rokhmah NN, Andrajati R, Radji M. Cross-sectional study of surgical prophylactic antibiotic administration in Marzoeki Mahdi Hospital, Bogor, Indonesia. Asian J Pharm Clin Res 2017;10:21-3.

5. Cizman M. The use and resistance to antibiotics in the community. Int J Antimicrob Agents Netherlands 2003;21:297307.

6. Sözen H, Gönen I, Sözen A, Kutlucan A, Kalemci S, Sahan M. Application of ATC/DDD methodology to evaluate of antibiotic use in a general hospital in Turkey. Ann Clin Microbiol Antimicrob 2013;12:1-6. 
7. Monnet DL, Mölstad S, Cars O. Defined daily doses of antimicrobials reflect antimicrobial prescriptions in ambulatory care. J Antimicrob Chemother 2004;53:1109-11.

8. World Health Organization. World Health Organization. Guidelines for ATC classification and DDD assignment 2016 [Internet]. 19th ed. WHO Collab. Cent. Drug Stat. Methodol. Oslo, Norway: Norwegian Institute of Public Health; 2015. Available from: www.whocc.no [Last accessed on 10 Jan 2018]

9. Berrington A. Antimicrobial prescribing in hospitals: Be careful what you measure. J Antimicrob Chemother 2009;65:163-8.

10. Mahmood A, Ahmed A, Azim A, Ali A, Hassan NAGM, Shehab A, et al. Evaluation of the rational use of medicines (RUM) in four government hospitals in UAE. Saudi Pharm J King Saud University 2016;24:189-96.

11. Nelson S. How to calculate antimicrobial defined daily doses (DDDs) and DDDs per 1000 Patient Days Requirements. 2012.

12. Shea K, Florin K, Barlam T. When wonder drugs don't work how antibiotic resistance threatens childen, Senior, and Medically Vurnrable. Washington, DC 20009; 2001.

13. The Paediatric Formulary Committee (PFC). BNF For children [Internet]. London: British National Formulary Publications, Royal Pharmaceutical Society of Great Britain; 2009. Available from: www.pharmpress.com [Last accessed on 10 Jan 2018]

14. Suman RK, Ray IM, Mohanty NC, Mukhia RK, Deshmukh YA Assessment of usage of antibiotics and their pattern of antibiotic sensitivity test among childhood fever. Int J Pharm Pharm Sci 2014;6:296-9.

15. Katzung BG, Masters SB, Trevor AJ. Basic and Clinical Pharmacology. 12th ed. United States: The McGraw-Hill Companies, Inc; 2012.

16. Kementerian Kesehatan RI. Pedoman Pelayanan Kefarmasian Untuk Terapi Antibiotik. Jakarta; 2011.

17. MacKenzie FM. Antibiotic consumption in European hospitals consommation. Medicine Mal Infect 2005;35:121-2.

18. Serife Akalin. Antimicrobial consumption at a university hospital in Turkey. Afr J Microbiol Res 2012;6:4000-5.

19. Vaccheri A, Silvani MC, Bersaglia L, Motola D, Strahinja P, Vargiu A, et al. A 3 y survey on the use of antibacterial agents in five Italian hospitals. J Antimicrob Chemother 2008;61:953-8.

20. Jasso Gutierrez L, Santos Preciado JI. Use of defined-daily-doses per 100 bed-days for measuring consumption of anti-infectives in a pediatric hospital. Am J Heal Pharm. ASHP 2010;67:14-5.

21. Wirahmi N, Halim A, Lucida H. Analisa penggunaan kombinasi gentamisin dan ampisilin pada pasien pediatri di bangsal anak. Universitas Andalas; 2011.

22. Kuster SP, Ruef C, Ledergerber B, Hintermann A, Deplazes C, Neuber L, et al. Quantitative antibiotic use in hospitals: comparison of measurements, literature review, and recommendations for a standard of reporting. Infection 2008;36:549-59. 